\title{
Isolation and Characterization of Bacillus Subtilis KC3 for Amylolytic Activity
}

\author{
Vijayalakshmi, K. Sushma, S. Abha, and P. Chander
}

\begin{abstract}
Microbial $\alpha$-amylase is a highly demanded industrial enzyme with extensive commercial applications in various sectors. Studies were carried out with a bacterial strain producing extracellular $\alpha$-amylase, isolated from rhizospheric soil of Euphorbia hirta. The isolate was gram positive, motile rod, bearing terminal endospore. It exhibited $>98 \%$ similarity with the reference strains in the GenBank. The phylogenetic tree constructed on the basis of $16 \mathrm{~S}$ rRNA gene sequences revealed that it clustered with the closest members of Bacillus subtilis and identified as Bacillus subtilis KC3. Furthermore, the effects of incubation period, temperature, $\mathrm{pH}$, different carbon and nitrogen sources, metal salts and different substrate concentrations of the medium were optimized. The maximum enzyme production was found after $48 \mathrm{~h}(22.92 \mathrm{U} / \mathrm{ml})$ of incubation at temperature $40^{\circ} \mathrm{C}$ and $\mathrm{pH}$ 7. The optimal temperature and $\mathrm{pH}$ for enzyme activity were $50^{\circ} \mathrm{C}$ and 6.5 respectively. Barley starch $(27.27 \mathrm{U} / \mathrm{ml})$ was observed to be the best inducer followed by corn starch $(24.30 \mathrm{U} / \mathrm{ml})$ and maltose $(19.10 \mathrm{U} / \mathrm{ml})$. The addition of glucose to the culture medium greatly reduced the synthesis of $\alpha$-amylase $(5.45 \mathrm{U} / \mathrm{ml})$ which demonstrates that a classical glucose effect is operative in this organism. The effects of different metal ions $\left(\mathrm{Ca}^{2+,} \mathrm{Fe}^{2+}, \mathrm{Mg}^{2+}\right.$, $\mathrm{Zn}^{2+}$ and $\mathrm{Cu}^{2+}$ ) on amylolytic activity were investigated and it was found that $0.1 \%$ of $\mathrm{Ca}^{2+}$ increased enzyme production $(28.83 \mathrm{U} / \mathrm{ml})$, whereas other metal ions exhibited inhibitory effects. The enzyme production was maximum at $2 \%$ substrate (starch) concentration, which declined beyond it. These characteristics of Bacillus subtilis $\mathrm{KC3}$, suggest that this is a promising isolate which merits further investigations for potential applications in various biotechnological processes.
\end{abstract}

Index Terms- $-\alpha$-amylase, bacillus subtilis $\mathrm{KC3}$, euphorbia hirta, rhizospheric soil

\section{INTRODUCTION}

Amylases constitute a group of industrial enzymes, which alone covers approximately $30 \%$ of the enzyme market. They have opened new frontiers of many commercial biotechnological processes including renewable energy, pharmaceuticals, saccharification or liquefication of starch, detergent industries, warp sizing of textiles, fibres, paper industries, foodstuffs, baking, clarification of haze formed in beer or fruit juices and for pretreatment of animal feed to improve digestibility [1]- [6]. Amylases are known to be produced by a variety of bacteria and fungi and their applications at industrial level have stimulated interest to explore their amylolytic activity in several microbes to be used as bioresources [2], [7]-[9]. The horizon got further

Manuscript received August 10, 2012; revised September 20, 2012.

The authors are with the Department of Botany, P. U., Patna- 800005 , Bihar, India (e-mail: vijayalakshminishant@gmail.com; ksushmabt@gmail.com; Tel. +91-9470412424, singh.abhabt@gmail.com; Tel.+91-9430458247, cp_ptc@yahoo.co.in). magnified with the discovery of new strains of microorganisms and development of more efficient production strategies because microbes have substantial potential to contribute to several commercial purposes. Moreover, microbial amylases have a broad spectrum of industrial applications as they are more stable with great genetic diversity, high enzymatic activity in a wide range of conditions (extreme $\mathrm{pH}$, temperature, osmolarity, pressure etc.), simple and cost effective production and easy manipulation to obtain enzymes of desired characteristics [10] $-[12]$.

The production of microbial amylases from bacteria is dependent on the type of strain, composition of medium, method of cultivation, cell growth, nutrient requirements, incubation period, $\mathrm{pH}$, temperature, metal ions and thermostability [8]. In fact, such industrially important microorganisms found within the genus Bacillus, can be exploited commercially due to their rapid growth rate leading to short fermentation cycles, capacity to secrete proteins into the extracellular medium and safe handling [8]. Bacillus is endowed to produce thermostable $\alpha$-amylase and also large quantities of other enzymes. Indeed, $60 \%$ of commercially available enzymes are obtained from different species of Bacillus i.e. B. subtilis, B. stearothermophilus, $B$. licheniformis and B. amyloliquefaciens [11]. Some Bacillus strains produce enzyme in the exponential phase, whereas some others in the mid stationary phase. Though, different Bacillus species have similar growth patterns and enzyme profiles, but their optimized conditions vary, depending upon the strain.

The objectives of the present study are to screen Bacillus species isolated from Euphorbia hirta rhizosphere in order to study their suitability with regard to $\alpha$-amylase production.

\section{MAterial AND MethodS}

\section{A. Sampling}

The samples of rhizospheric soil of rooted Euphorbia hirta were collected from the Research Garden, Department of Botany, Patna University, Patna $\left(25^{\circ} 36^{\prime} 39.6^{\prime \prime} \mathrm{N}\right.$ $85^{\circ} 08^{\prime} 38.4^{\prime \prime} \mathrm{E}$ ) and stored for further study.

\section{B. Isolation, Screening and Characterization}

Bacteria were isolated by serial dilution and streak plate methods. The aliquots $(0.1 \mathrm{ml})$ were plated in triplicates on Nutrient Agar (NA) medium [(w/v) $0.5 \%$ peptone; $0.3 \%$ beef extract; $0.5 \% \mathrm{NaCl} ; 1.5 \%$ agar, $\mathrm{pH}$ 7] and incubated at $30 \pm 2^{\circ} \mathrm{C}$ for $72 \mathrm{~h}$. The nutrient agar plates containing $1 \%$ starch (Starch Agar plates) were inoculated with test bacterial isolates and incubated at $30 \pm 2^{\circ} \mathrm{C}$. The $\alpha$-amylase producing 
bacteria were screened out by flooding the plates with Lugol's iodine solution [w/v $1 \%$ iodine in $2 \%$ potassium iodide] after $48 \mathrm{~h}$ of incubation. The isolate showing maximum clear halo zone was designated as $\mathrm{KC} 3$ and further analysed. The culture was maintained on NA slants at $-20^{\circ} \mathrm{C}$.

Phenotypic characterization of the isolate was done by different tests referring to Bergey's Manual of Determinative Bacteriology and Agriculture handbook [13]-[14]. For genotypic characterization, genomic DNA was extracted from the isolate using Chromous Genomic DNA isolation kit (RKT09). The amplification of 16S rRNA gene was carried out by using Thermal cycler (ABI 2720) in $100 \mu$ l reaction mixture containing $2.5 \mathrm{mM}$ each of four dNTP, 10X PCR buffer, 3U of Taq DNA polymerase, $10 \mathrm{ng}$ template DNA and 400ng each of primer (F) 5'-AGA GTR TGA TCM TYG CTW AC-3' primer (R) 5'-CGY TAM CTT WTT ACG RCT-3'. The amplification programme was set as initial denaturation at $94^{\circ} \mathrm{C}$ for $5 \mathrm{~min}$, followed by 35 cycles of $94^{\circ} \mathrm{C}$ for $30 \mathrm{~s}, 55^{\circ} \mathrm{C}$ for $30 \mathrm{~s}, 72^{\circ} \mathrm{C}$ for $2 \mathrm{~min}$ and a final extension at $72^{\circ} \mathrm{C}$ for $5 \mathrm{~min}$. The sequencing was performed according to the manufacturer's protocol using Big Dye Terminator Cycle Sequencing Kit (v3.1, Applied Biosystems) and analyzed in an Applied Biosystems Analyzer. The sequence of $16 \mathrm{~S}$ rDNA (1468 bp) was aligned by using the BLASTN program to identify the most similar sequence in the database [15] and has been submitted to the GenBank (National Center for Biotechnology Information, NCBI, Bethesda, Maryland, USA) under accession number HM195191. 16S rDNA sequences of different strains of Bacillus subtilis and its phylogenetically related species and genera were downloaded from GenBank database (http://www.ncbi.nlm.nih.gov/entrez) and aligned to construct a neighbour-joining phylogenetic tree using Clustal W algorithm with the help of MEGA software version 4.1 [16].

\section{Enzyme Production}

Erlenmeyer flasks $(250 \mathrm{ml})$ containing $60 \mathrm{ml}$ of amylase producing broth medium [(w/v) $0.6 \%$ peptone; $0.05 \%$ $\mathrm{MgSO}_{4} ; 0.05 \% \mathrm{KCl} ; 1 \%$ starch; $\mathrm{pH}$ 7] were inoculated with $1 \%$ overnight $(24 \mathrm{~h})$ grown culture (approximately $2 \times 10^{6}$ $\mathrm{CFU} / \mathrm{ml}$ ) and incubated at $30 \pm 2^{\circ} \mathrm{C}$ in triplicates. At constant intervals $(24 \mathrm{~h})$, the samples were harvested and the growth was determined by measuring the absorbance at $600 \mathrm{~nm}$. The enzyme was extracted from the stationary phase culture. Cells were removed by centrifugation ( $8,000 \mathrm{rpm}$ for $20 \mathrm{~min}$ ) and supernatants were used for enzyme assay [17].

\section{Enzyme Assay}

$\alpha$ - amylase was assayed by adding $1 \mathrm{ml}$ of enzyme to $1 \mathrm{ml}$ soluble starch (1\%) in $0.1 \mathrm{M}$ phosphate buffer $(\mathrm{pH}$ 6.5) and incubated at $50^{\circ} \mathrm{C}$ for $10 \mathrm{~min}$. The reaction was stopped by adding $3 \mathrm{ml}$ of 3, 5-dinitrosalicylic acid reagent [17]. Following the color development, the absorbance was measured at $575 \mathrm{~nm}$ using double beam UV/VIS spectrophotometer (Systronics, 119). One enzyme unit(unit/ml) is defined as the amount of enzyme which releases $1 \mu$ mole glucose.

\section{E. Effect of Incubation Period}

The effect of incubation period was determined by incubating production medium for different incubation periods $(24,48,72$ and $96 \mathrm{~h})$.

\section{F. Effect of $p H$ and Temperature}

The effect of varying $\mathrm{pH}(5.0,5.5,6.0,6.5,7.0,7.5,8.0$, 8.5 and 9.0$)$ and temperature $\left(30,40,50,60,70\right.$ and $\left.80^{\circ} \mathrm{C}\right)$ on $\alpha$-amylase production medium was investigated.

\section{G. Effect of Carbon and Nitrogen Sources}

The effect of carbon (barley starch, corn starch, wheat starch, maltose and glucose) and nitrogen sources (peptone, tryptone, yeast extract and sodium nitrate) each at $1 \%$ concentration was investigated on amylase production.

\section{H. Effect of Metal Salts}

The effect of metal salts on $\alpha$ - amylase production was studied by adding different metal salts like $\mathrm{FeSO}_{4}, \mathrm{MgSO}_{4}$, $\mathrm{ZnSO}_{4}, \mathrm{CuSO}_{4}$ and $\mathrm{CaCl}_{2}$ in the medium at $0.1 \%$ concentration.

\section{Effect of Substrate Concentration}

Effect of substrate concentration was measured at different concentrations of starch $(1.0,2.0,3.0,4.0$ and $5.0 \%)$ in the production medium.

\section{J. Effect of $p H$ and Temperature on Enzyme Activity}

The $\mathrm{pH}$ optimum of the enzyme was assayed by varying the $\mathrm{pH}((5.0,5.5,6.0,6.5,7.0,7.5,8.0,8.5$ and 9.0$)$ at intervals of 0.5 units of the reaction mixture by using $0.1 \mathrm{M}$ phosphate buffer. The temperature optimum of the enzyme was evaluated by measuring the $\alpha$-amylase activity at different temperatures $\left(30,40,50,60,70\right.$, and $\left.80^{\circ} \mathrm{C}\right)$ in $0.1 \mathrm{M}$ sodium phosphate buffer at optimum $\mathrm{pH}$.

\section{K. Statistical Analyses}

Data were statistically analysed using Statistics Package for the Social Sciences, SPSS-X Chicago, USA. All analyses were performed at $\mathrm{p} \leq 0.05$.

\section{RESULTS AND DISCUSSION}

The bacterial strains isolated from rhizosphere of Euphorbia hirta were screened for $\alpha$-amylase activity. After Lugol's staining, the isolate KC3 was selected on the basis of maximum halo zone $(2.3 \mathrm{~cm})$ developed on the Starch Agar plates. The isolate was gram positive, motile rod measuring 3.1 to $3.5 \mu \mathrm{m}$ in length and approximately $0.5 \mu \mathrm{m}$ in width, bearing terminal endospore,. The strain exhibits moderate growth at $\mathrm{pH} 5.0$ to $9.0, \mathrm{NaCl}$ concentrations $2.5 \%$ to $7 \%$ and temperature $30^{\circ} \mathrm{C}$ to $42^{\circ} \mathrm{C}$. It was aerobic, catalase positive having distinct fermentation profiles of different carbon sources. The strain possessed the ability to hydrolyze starch, gelatine and casein. On the basis of the observed phenotypic characteristics the above cited isolate was grouped into genus Bacillus. Furthermore, it exhibited high level of similarity (>98\%) with the closest known species in the database. The phylogenetic tree based on bacterial $16 \mathrm{~S}$ rDNA sequence and closest reference strains downloaded from the database, showed a significant relationship with Bacillus subtilis (Fig. 1). Henceforth, this isolate was identified as Bacillus subtilis KC3. 


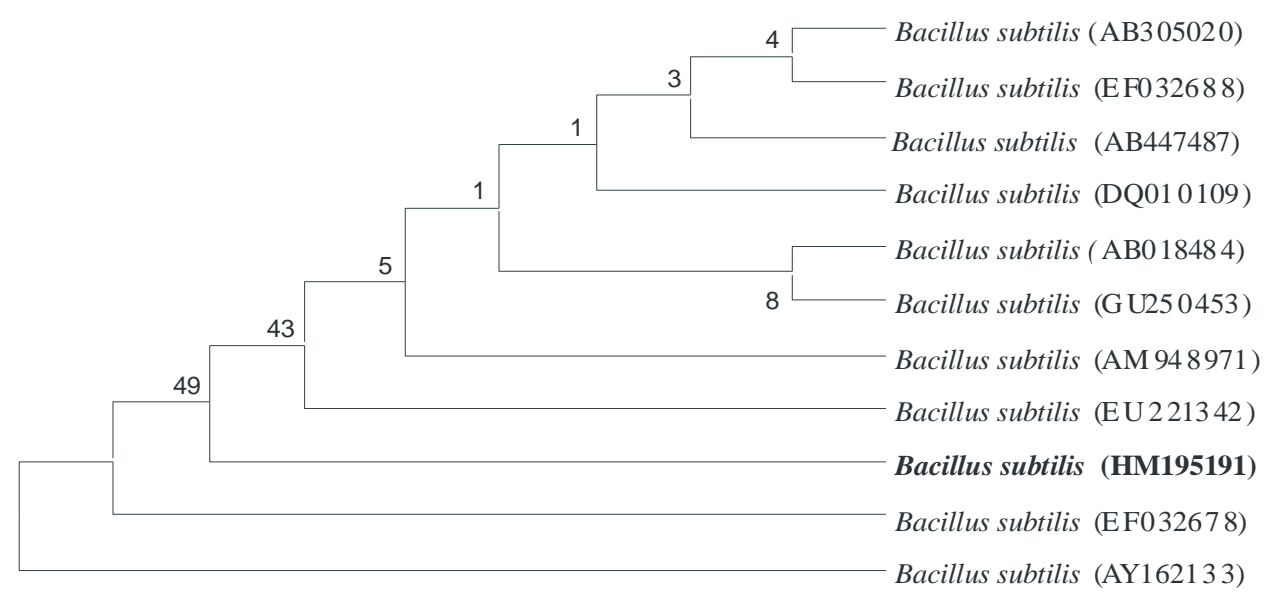

Fig. 1. Phylogenetic tree showing genetic relationship of bacillus subtilis with taxonomically similar strains, species and genus based on 16s rDNA sequences. genbank accession number of each isolate is given in parentheses. bootstrap values based on 1000 replicates are shown next to the branches.

The optimum incubation period for $\alpha$-amylase production was $48 \mathrm{~h}(22.92 \mathrm{U} / \mathrm{ml})$ (Fig. 2). Incubation beyond the optimum time course was generally accompanied by a decrease in the growth rate and enzyme productivity, which gradually declined to $5.48 \mathrm{U} / \mathrm{ml}$ after $96 \mathrm{~h}$ of incubation. The decreased activity in the later phase of growth was probably due to catabolite repression by readily metabolizable substrate glucose [18]. The short incubation period for Bacillus sp. than other bacteria and fungi offers unique potential for inexpensive enzyme production [19]-[20]. Similar results have been reported in Bacillus flavothermus after $24 \mathrm{~h} \mathrm{[21]} \mathrm{and} \mathrm{in} \mathrm{Bacillus} \mathrm{amyloliquefaciens} \mathrm{after} 72 \mathrm{~h}$ [22]. At pH 7, optimum amount (23.30 U/ml) of amylase was produced and below and above this $\mathrm{pH}$, the production gets either decreased or denatured (Fig. 3). Different organisms have different $\mathrm{pH}$ optima, and decrease or increase in $\mathrm{pH}$, on either side of the optimum value results in poor microbial growth [23]. These results suggest that there is a stimulation of enzyme synthesis at neutral $\mathrm{pH}$ and that the higher enzyme production at this $\mathrm{pH}$ was a result of increased cell growth. The $\mathrm{pH}$ of 6 and 7 has been reported for normal growth and enzyme activity in Bacillus strain isolated from soil [12]-[24]. Neutral $\mathrm{pH}$ was found to be optimal for amylase production as also reported in $B$. thermooleovorans NP54 [25], $B$. coagulans [26], B. licheniformis [27], B. subtilis JS-2004 [28] and B. brevis [29]. The results illustrated in Fig. 4 showed a positive correlation between the growth/enzyme production and the incubation temperature up to $40^{\circ} \mathrm{C}$, followed by a gradual decrease. At higher temperature the bacterial growth gets suppressed and consequently enzyme formation also gets inhibited [8]. The effect of different carbon sources suggest that $\alpha$-amylase was an inducible enzyme and gets induced in the presence of carbon sources (Fig. 5). Barley starch $(27.27 \mathrm{U} / \mathrm{ml})$ and corn starch $(24.30 \mathrm{U} / \mathrm{ml})$ appeared to be the best inducers followed by maltose $(19.10 \mathrm{U} / \mathrm{ml})$. The superiority of amylase production with complex substrates have been earlier reported [30]. Natural sources could serve as economical and readily available raw material for production of valuable enzymes. From the present findings, it is evident that the induction of $\alpha$-amylase requires substrates having $\alpha-1,4$ glycosidic bond, including starch and maltose, but glucose represses its production (Fig. 5). The biosynthesis of $\alpha$-amylase in most species of the genus
Bacillus is repressed by readily metabolizable substrates, especially glucose, by a mechanism of catabolite repression, mediated by the protein encoded by the CreA gene [31]-[32]. Among the organic nitrogen sources, peptone $(24.64 \mathrm{U} / \mathrm{ml})$ proved to be the most suitable followed by tryptone (21.66 $\mathrm{U} / \mathrm{ml}$ ) as compared to the inorganic $\mathrm{N}_{2}$ sources i.e. 12.34 $\mathrm{U} / \mathrm{ml}$ (Fig. 5). It has been previously found that organic nitrogen sources like peptone and yeast extract usually have stimulating effects [33] and our findings are similar to them. Various other organic nitrogen sources have also been reported to support maximum $\alpha$-amylase production by various Bacillus species [34]-[39]. Maximum enzyme activity was found with $2 \%$ starch as the substrate when the crude enzyme was allowed to react with different substrate concentrations.

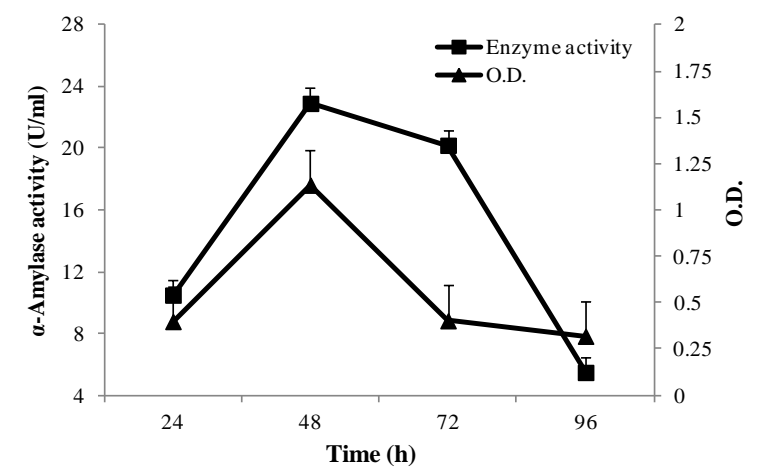

Fig. 2. Effect of incubation time on $\alpha$-amylase production from bacillus subtilis (HM195191). Bars indicate standard error of mean $(n=3)$.

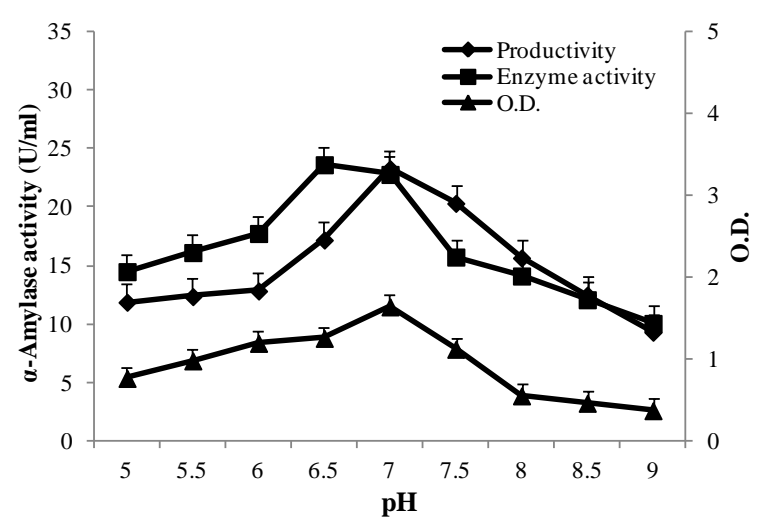

Fig. 3. Effect of $\mathrm{pH}$ on -amylase productivity and activity of bacillus subtilis (hm195191). bars indicate standard error of mean $(n=3)$. 


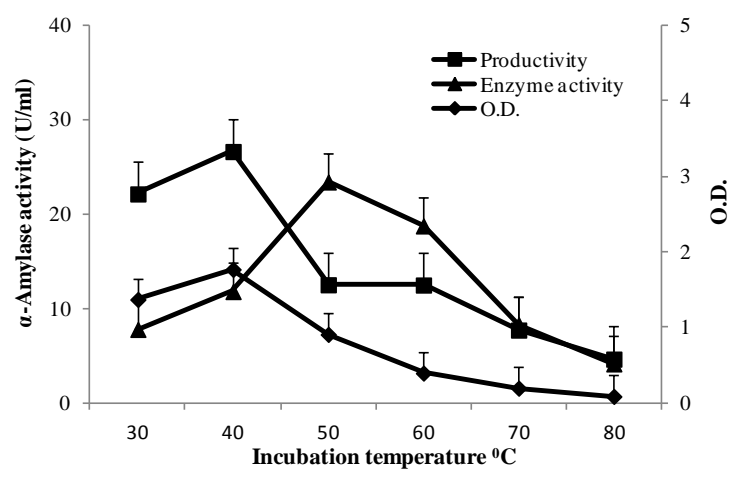

Fig. 4. Effect of temperature on $\alpha$-amylase productivity and activity of bacillus subtilis (HM195191). Bars indicate standard error of mean ( $n=3)$.

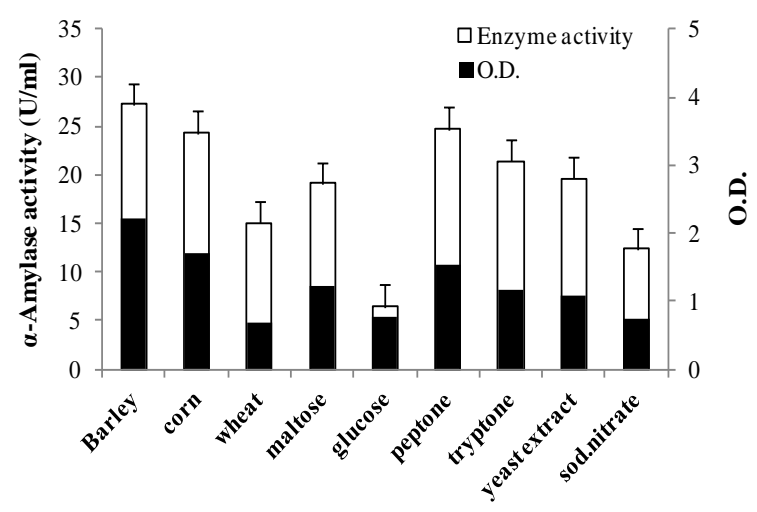

Fig. 5. Effect of different carbon and nitorgen sources on $\alpha$-amylase production from bacillus subtilis (HM195191). bars indicate standard error of mean $(n=3)$.

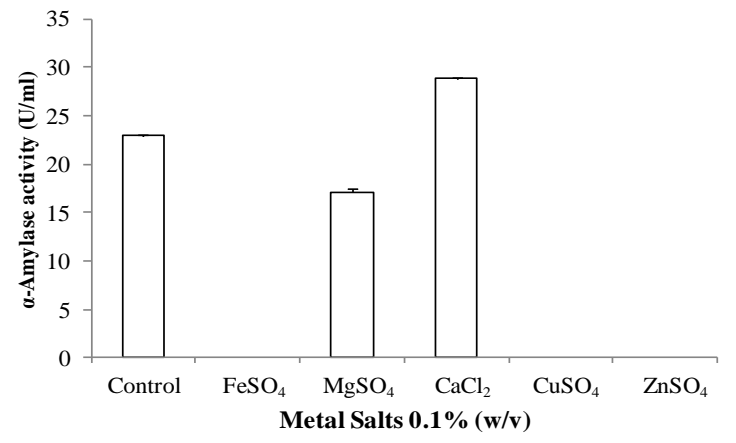

Fig. 6. Effect of metal salts on $\alpha$-amylase production from bacillus subtilis (HM195191). Bars indicate standard error of mean $(n=3)$.

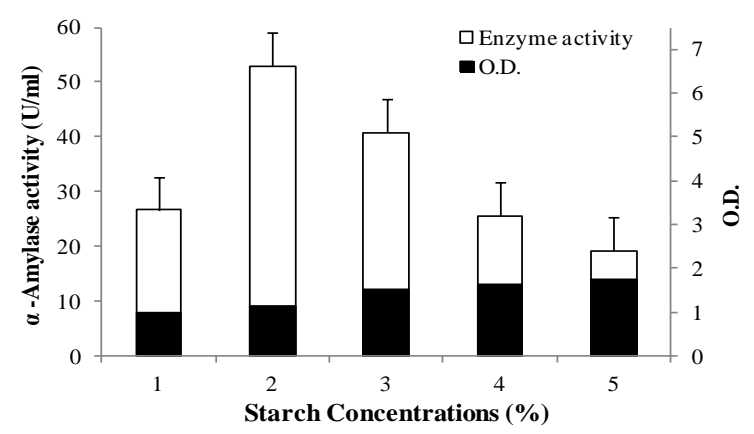

Fig. 7. Effect of starch cncentration on $\alpha$-amylase production from bacillus subtilis (HM195191). Bars indicate standard error of mean $(n=3)$.

Most of the $\alpha$-amylases are known to be metalloenzymes. Supplementation of salts of certain metal ions provided good growth of bacteria and thereby better enzyme production. The production of $\alpha$-amylase by $B$. subtilis $\mathrm{KC} 3$ was increased in the presence of $0.1 \% \mathrm{CaCl}_{2}(28.83 \mathrm{U} / \mathrm{ml})$, which is similar to Bacillus sp. TSCVKK and Bacillus sp. 64
[40]-[41]. $\mathrm{Ca}^{2+}$ had significant effects on the metabolism and physiology of bacteria and that was also found to be effective on enzyme activity [42]. The other metal salt like $\mathrm{MgSO}_{4}$ decreased enzyme production $(17.44 \mathrm{U} / \mathrm{ml})$, whereas $\mathrm{FeSO}_{4}$, $\mathrm{CuSO}_{4}$ and $\mathrm{ZnSO}_{4}$ at $0.1 \%$ concentration completely inhibited $\alpha$-amylase production (Fig. 6). The inhibitory effects of some of the salts may be related to the $\mathrm{pH}$ changes associated with their use in the medium. Kiran et al. [40] confirms that the presence of $\mathrm{ZnSO}_{4}$ had a potent inhibitory effect on the production of $\alpha$-amylase from Bacillus sp. K-12. The results illustrated in Fig. 7 reveal that the enzyme production was increased 1.98 fold when starch concentration increased to $2 \%$ compared with the production at $1 \%$. However, the $\alpha$-amylase production declined when the starch concentrations increased beyond $2 \%$ (Fig. 7). The reduction in enzyme productivity at a high substrate concentration is more likely due to the high viscosity of the medium affecting the availability of oxygen concentration required for the microbial growth [43].

In the present communication the enzyme was optimally active and stable at $\mathrm{pH} 6.5(23.65 \mathrm{U} / \mathrm{ml})$ which is within the range of values for most starch degrading bacterial strains [44]. A considerable amount of activity (19.26 to 22.02 $\mathrm{U} / \mathrm{ml}$ )) was obtained at alkaline $\mathrm{pH}$ (Fig. 3) showing the wide application of enzyme. The optimum temperature for $\alpha$-amylase activity was $50^{\circ} \mathrm{C}$. At $60^{\circ} \mathrm{C}$ the maximal enzyme activity was recorded $(80.07 \%)$ but the activity sharply declined (38.36\%) at $70^{\circ} \mathrm{C}$ (Fig. 4). The optimum temperature for amylase activity is usually related to the growth temperature of the microorganism. However, it was also reported that extracellular enzymes were optimally active at temperatures above and beyond the host organism's optimum growth temperature [45]. The Bacillus subtilis KC3 has optimum growth temperature around $33^{\circ} \mathrm{C}$, while the crude amylase from this bacterium is optimally active at $50^{\circ} \mathrm{C}$, which is comparable with that described for $B$. amyloliquefaciens $\alpha$-amylase [46]. Amongst the physiological parameters, temperature and $\mathrm{pH}$ of the growth medium play an important role in production and activity of microbial enzymes [47]. The present study shows that barley starch is a good substrate for amylase production by Bacillus subtilis KC3. The characteristic temperature, slightly acidic $\mathrm{pH}$, short lag and initial stationary phase are novel features which could be commercially exploited for production of $\alpha$-amylase in starch and other food industries.

\section{ACKNOWLEDGMENTS}

The authors are grateful to the Head, Department of Botany, P.U., for providing laboratory facilities.

\section{REFERENCES}

[1] D. A. Mitchell and B. K. Lonsane, in General principles of Solid State fermentation Monogram, W. Doelle, C. Rolz, Ed. Oxford, London, 1990.

[2] I. Akpan, M. O. Bankole, A. M. Adesemowo, and G. O. Latunde-Dada, "Production of amylase by Aspergillus niger in a cheap solid medium using rice bran and agricultural material," Trop. Sci., vol. 39, pp. 77-79, $1999 b$.

[3] N. Oudjeriouat, Y. Moraiau, M. Santimone, B. Svenssen, G Marchis-Mouren, and V. Desseaux, "On the mechanism of amylase: A carbon and cyclodextrin inhibition of barley amylase isozymes," Eur. J. Biochem. FEBS, vol. 270, pp. 3871-3879, Sept. 2003. 
[4] M. Asghar, M. J. Asad, and M. Arshad, "Alpha-amylase from Aspergillus niger in waste bread medium," in Proc. 2nd Int. Symp. New Technol. for Environ. Monit and Agro-Appil. Oct. 18-20, 2000.

[5] H. Sun, P. Zhao, X. Ge, Y. Xia, Z. Hao, J. Liu, and M. Peng, "Recent advances in microbial raw starch degrading enzymes," Appl. Biochem. Biotechnol, vol. 160, pp. 988-1003, Feb. 2010.

[6] B. Hanes and S. Stedt, Milling and Baking Technology, John Wiley and Sons, USA. 1988, pp. 415-70.

[7] A. N. Oliveira, L. A. Oliveira, J. S. Andrade, and A. F. Junior, "Rhizobia amylase production using various starchy substances as carbon substrates," Brazi. J. Microbiol., vol. 38, pp. 208-216, June 2007.

[8] A. Pandey, P. Nigam, C. R. Soccol, V. T. Soccol, D. Singh, and R. Mohan, "Advances in microbial amylases," Biotechnol. Appl. Biochem., vol. 31, pp. 135-152, March 2000.

[9] E. A. Abu, S. A. Ado, and D. B. James, "Raw Starch degrading amylase production by mixed culture of Aspergillus niger and Saccharomyces cerevisae grown on Sorghum pomace," Afr. J. Biotechnol., vol. 4, no.8, pp. 785- 790, Aug. 2005 .

[10] M. S. Tanyildizi, D. Ozer, and M. Elibol, "Optimization of amylase production by Bacillus sp. using response surface methodology," Process Biochem., vol. 40, pp. 2291-2296, June 2005.

[11] A. Burhan, U. Nisa, C. Gokhan, C. Omer, A. Ashabil, and G. Osman, "Enzymatic properties of a novel thermophilic, alkaline and chelator resistant amylase from an alkalophilic Bacillus sps. Isolate ANT- 6," Proc. Biochem, vol. 38, pp. 1397-1403, May 2003.

[12] R. Vidyalakshmi, R. Paranthaman, and J. Indhumathi, "Amylase Production on Submerged Fermentation by Bacillus spp," W. J. Chem., vol. 4, no. 1, pp. 89-91, 2009.

[13] J. G. Holt, N. R. Kreig, P. H. A. Sneath, J. T. Staley, and S. T. Williams. Bergey's Manual of Determinative Bacteriology, 9th ed., Williams and Wilkins, Baltimore, Maryland, USA, 1994.

[14] R. E. Gordon, W. C. Haynes, and C. H. Pang, "The genus Bacillus," in Agriculture Handbook, Washington, D. C: US Dept. of Agriculture. no. 427, pp. 1-99, 1973.

[15] S. F. Altschul, W. Gish, W. Miller, E. W. Myers, and D. J. Lipman, "Basic local alignment search tool", J. Mol. Biol, vol. 215, pp. 403-410, Oct. 1990.

[16] K. Tamura, J. Dudley, M. Nei, and S. Kumar, "MEGA: Molecular Evolutionary Genetics Analysis (MEGA) software version 4.0," Mol. Bio. Evolution, vol. 24, pp. 1596-1599, Aug. 2007.

[17] G. L. Miller, "Use of dinitrosalicyclic acid reagent for determination of reducing sugar," Anal. Chem., vol. 31, pp. 42, March 1959.

[18] L. Lin, C. Chyau, and W. H. Hsu, "Production and properties of a raw starch-degrading amylase from thermophilic and alkaliphilic Bacillus sp. TS-23," Biotech. Appl. Biochem., vol. 28, pp. 61-68. Aug. 1998.

[19] P. Bernfeld, "Methods in Enzymology," in S. P. Colowick, and N. O. Kaplan, Ed. Academic Press, New York. 1955, vol. 1, pp. 149.

[20] A. A. Saad, "Isolation, Phylogeny and Characterization of New $\alpha$-amylase Producing Thermophilic Bacillus sp. from the Jazan Region, Saudi Arabia," Int. J. Biotech. Biochem., vol. 6, pp. 537-547, 2010.

[21] F. Torney, L. Moeller, A. Scarpa, and K. Wang, "Genetic engineering approaches to improve bioethanol production from maize," Current Opinion Biotechnol., vol. 18, pp. 193-199, June 2007.

[22] E. Sarikaya and V. Gurgun, "Increase of the $\alpha$-amylase yield by some Bacillus strains," Turkey J. Biol, vol. 24, pp. 299-308, May 2000.

[23] M. V. Ramesh and B. K. Lonsane, "Regulation of alpha-amylase production in Bacillus licheniformis M 27 by enzyme end-products in submerged fermentation and its overcoming in solid state fermentation system," Biotechnol. Lett., vol. 13, no. 5, pp. 355-360, May 1991.

[24] L. S. Mishra and N. Behera, "Amylase activity of a starch degrading bacteria isolated from soil receiving kitchen wastes," Afr. J. Biotechnol, vol. 7, pp. 3326-3331, Sept. 2008.

[25] R. V. Malhotra, S. M. Noorwez, and T. Satyanarayana, "Production and partial characterization of thermostable and calcium-independent $\alpha$-amylase of an extreme thermophile Bacillus thermooleovorans NP 54," Lett. Appl. Microbiol., vol. 31, pp. 378-384, Nov. 2000.

[26] S. Medda and A. K. Chandra, "New strains of Bacillus licheniformis and Bacillus coagulans producing thermostable $\alpha$-amylase active at alkaline pH," J. Appl. Bacteriol., vol. 48, pp. 47-58, 1980.

[27] T. Krishnan and A. K. Chandra, "Purification and Characterization of $\alpha$-amylase from Bacillus licheniformis CUMC305," Appl. Environ. Microbiol., vol. 46, no. 2, pp. 430-437, Aug. 1983.

[28] M. Asgher, M. Javaid Asad, S. U. Rahman, and R. L. Legge, "A thermostable $\alpha$-amylase from a moderately thermophilic Bacillus subtilis strain for starch processing," J. Food Eng., vol. 79, pp. 950-955, Apr. 2007.
[29] V. T. Tsvetkov and E. I Emanuilova, "Purification and properties of heat stable $\alpha$-amylase from Bacillus brevis," Appl. Microbiol. Biotechnol., vol. 31, no. 3, pp. 246-248, Sept. 1989.

[30] R. Sexana, K. Dutt, L. Agarwal, and P. Nayyar, "A highly thermostable and alkaline amylase from a Bacillus sp. PN5," Bioresource Technol., vol. 98, pp. 260-265, Jan. 2007.

[31] C. Haseltine, M. Rolfsmeier, and P. Blum, "The glucose effect and regulation of $\alpha$-amylase synthesis in the hyperthermophilic archaeon Sulfolobus solfataricus," J. Bacteriol., vol. 178, pp. 945-950, Feb. 1996.

[32] M. Kato, K. Sekine, and N. Tsukagoshi, "Sequence-specific binding sites in the Taka-amylase A G2 promoter for the CreA repressor mediating carbon catabolite repression," Biosci. Biotechnol. Biochem. vol. 60, pp. 1776-1779, 1996.

[33] C. J. Hewitt and G. L. Solomons, "The production of $\alpha$-amylase by Bacillus amyloliquefaciens, in a complex and a totally define synthetic culture medium," J. Industrial Microbiol., vol. 17, pp. 96-99, 1996.

[34] I. Rasooli, S. D. A. Astaneh, H. Borna, and K. A. Barchini, "A thermostable $\alpha$-amylase producing natural variant of Bacillus spp. isolated from soil in Iran," Am. J. Agri, Bio. Sci., vol. 3, no. 3, pp. 591-596, Sept. 2008.

[35] Z. Konsoula and M. Liakopoulou-Kyriakides, "Co-production of $\alpha$-amylase and $\beta$-galactosidase by Bacillus subtilis in complex organic substrates," Bioresource Technol., vol. 98, pp. 150-157, Jan. 2007.

[36] N. Akcan, F. Uyar, and A. Guven, "Alpha-amylase production by Bacillus subtilis RSKK96 in submerged cultivation," Kafkas Univ. Vet. Fak. Derg, vol. 17, pp. 17-22, 2011.

[37] N. Bozic, J. Ruiz, J. Lopez-Santin, and Z. Vujcic, "Production and properties of the highly efficient raw starch digesting $\alpha$-amylase from a Bacillus licheniformis ATCC 9945a," Biochem. Eng. J., vol. 53, pp. 203- 209, Jan. 2011

[38] P. V. D. Aiyer, "Effect of C: $\mathrm{N}$ ratio on alpha amylase production by Bacillus licheniformis SPT 27," Afr. J. Biotechnol., vol. 3, no. 10, pp. 519-522, Oct. 2004

[39] Z. Baysal, F. Uyar, and C. Aytekin, "Production of $\alpha$-amylase by thermotolerant Bacillus subtilis in the presence of some carbon, nitrogen containing compounds and surfactants," Ann. Microbiol., vol. 53, no. 3, pp. 323-328, 2003.

[40] K. K. Kiran and T. S. Chandra, "Production of surfactant and detergent-stable, halophilic, and alkalitolerant alpha-amylase by a moderately halophilic Bacillus sp. strain TSCVKK," Appl. Microbiol. Biotechnol., vol. 77, pp. 1023-1031, 2008.

[41] J. M. Khire and A. Pant, "Thermostable, salt-tolerant amylase from Bacillus sp. 64," W. J. Microbiol. Biotechnol., vol. 8, pp. 167-170, 1992.

[42] S. S. Deshpande and M. Cheryan, "Effects of phytic acid, divalent cation and their interactions on $\alpha$-amylase activity," J. Food. Sci., vol. 49, pp. 516-519, 1984.

[43] T. Agger, A. B. Spohr, and J. Nielsen, " $\alpha$-amylase production in high cell density submerged cultivation of Aspergillus oryza and $A$. nidulans," Appl. Microb. Biotech., vol. 55, pp. 81-84, 2001.

[44] R. Gupta, P. Gigras, H. Mohapatra, V. K. Goswami, and B. Chauhan, "Microbial $\alpha$ - amylases: A biotechnological perspective," Process Biochem., vol. 38, pp. 1599-1616, June 2003.

[45] C. Vieille and G. J. Zeikus, "Hyperthermophilic enzymes: sources, uses, and molecular mechanisms for thermostability," Microbiol. Mol. Bio. Rev., vol. 65, no. 1, pp. 1- 43, March 2001.

[46] E. S. Demirkan, B. Mikami, M. Adachi, T. Higa, and S. Utsumi, " $\alpha$-amylases from $B$. amyloliquefaciens: purification, characterization, raw starch degradation and expression in E. coli," Process Biochem., vol. 40, no. 3, pp. 2629- 2636, July 2005.

[47] S. Shafaat, M. Akram, and A. Rehman, "Isolation and characterization of a thermostable $\alpha$-amylase from Bacillus subtilis," Afr. J. Microbiol. Res., vol. 5, no. 20, pp. 3334-3338, Sept. 2011.

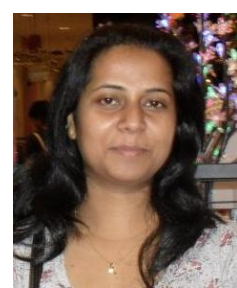

Vijayalakshmi was born in India, $14^{\text {th }}$ of November, 1983. Vijayalakshmi obtained her Master's degree in Botany in 2007. She is pursuing her Ph.D. on the topic "Study on cyanide producing rhizobacteria and their potential to suppress weed seedling growth" in the field of Botany from Patna University, Patna, India, under the guidance of Dr. Abha Singh. She has attended a workshop on molecular biology at B.I.T. ,Mesra (Ranchi, 2010). Vijayalakshmi is a life member of Indian Science Congress Association (ISCA). She has been awarded gold medal for exemplary performance in M.Sc. One of her paper has been selected as an excellent paper in the International Conference on Biological and Life 
Sciences (ICBLS, 2012) held at Singapore. She has deposited five nucleotide sequences at GenBank (National Center for Biotechnology Information, NCBI, Bethesda, Maryland, USA).

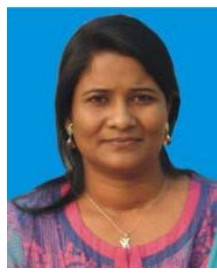

Sushma Kumari was born in India, on $1^{\text {st }}$ March, 1977. She awarded Ph.D. degree in Botany on "Investigations on the Microbial Diversity of Fermented Foods and Beverages" in 2010 from Patna University, Patna-800005, Bihar, India, under the supervision of Dr. Abha Singh, Associate Professor, Dept. of Botany, P.U. Patna, India.Currently, she is working as PDF (UGC) at Microbial Biodiversity Lab., Dept. of Botany, P.U. Patna, India, on the topic "Enhancement of Bioavailability of Iron in Lentil (Lens Culinaris) by Lactic Acid Fermentation". She had got Junior Reseach Fellowship in the major research work, funded by DBT, Govt. of India. She has attended workshops in the field of molecular biology held at B.I.T., Mesra (Ranchi, 2010) and CSMCRI (Bhavnagar, 2012). She has published two papers in different National and International journals. Ms. Sushma is a student member of Association of Microbiologists of India (AMI) and a senior member of Asia- Pacific Chemical, Biological and Environmental Engineering Society (APCBEES). One of her paper has been selected as an excellent paper in the International Conference on Biological and Life Sciences (ICBLS, 2012) held at Singapore. She has deposited twenty nucleotide sequences at GenBank (National Center for Biotechnology Information, NCBI, Bethesda, Maryland, USA).

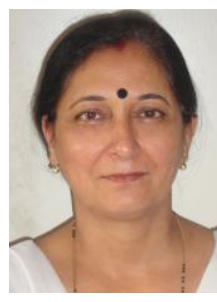

Abha Singh was born in India, on $10^{\text {th }}$ of July, 1960 Abha Singh obtained her Ph.D. degree in Botany on "Mutagenesis, ultra violet sensitivity and nitrogen metabolism of blue green algae under anaerobiosis" in the year 1990 from Banaras Hindu University, Uttar Pradesh, India, under the guidance of renowned scientist, Prof. H.D. Kumar FNA. Presently, she is working as an Associate Professor in the Department of Botany, Patna University, Patna, Bihar, India. She has successfully completed a major research project, funded by the Department of Biotechnology (DBT), Government of India. She has attended different workshops in the field of molecular biology held at B.I.T Mesra (Ranchi, 2010) and CSMCRI (Bhavnagar, 2012). She has published more than five papers in different National and International journals, such as Current Microbiology, Applied Phycology and Patna University Journal and is currently focussed in the field of microbiology and molecular biology and Plant tissue culture. Dr. Singh is a life member of Indian Science Congress Association (ISCA), Association of Microbiologists of India (AMI) and a senior member of Asia- Pacific Chemical, Biological and Environmental Engineering Society (APCBEES). She has won an excellent paper award recently, in the International Conference on Biological and Life Sciences (ICBLS, 2012) held at Singapore. She has deposited twenty five nucleotide sequences at GenBank (National Center for Biotechnology Information, NCBI, Bethesda, Maryland, USA).

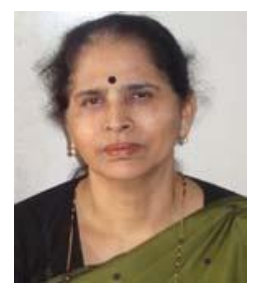

Chander Prabha was born in India, on $25^{\text {th }}$ February, 1954. She obtained her Ph.D. degree in Botany on "Cytotaxonomy and Biosystematic of some members of Compositae (Asteraceae)" in 1984 from Patna University, Patna-800005, Bihar, India, under the guidance of Late Prof. R. P. Roy, FNA, Jawahar Lal Nehru Fellow. Presently, she is working as an Associate Professor in the Department of Botany, Patna University, Patna, Bihar, India. She has successfully completed a major research project on medicinal plants, funded by the Department of Biotechnology (DBT), Government of India. She has attended different workshops on Plant Tissue Culture, Genetic Transformation, and Genome Analysis with molecular markers and PCR walking held at Energy \& Resources Institute (TERRI), New Delhi (2006). She has published more than ten papers in different National and International journals. Currently, she is focussed on different aspects of plant tissue culture, microbiology and molecular biology. Dr. Chander Prabha is a life member of Indian Science Congress Association, Indian Botanical Society, The Indian Society of Applied Biology (Advisor), Patna, and a senior member of Asia- Pacific Chemical, Biological and Environmental Engineering Society (APCBEES). One of her paper has been selected as an excellent paper in the International Conference on Biological and Life Sciences (ICBLS, 2012) held at Singapore. 